\title{
FLEXURAL BEHAVIOUR OF INTERIOR R.C.BEAM COLUMN JOINT WITH AND WITHOUT SLAB UNDER CYCLIC LOADING
}

\author{
Revathi.R ${ }^{1}$, Srisanthi .V.G ${ }^{2}$ \\ ${ }^{I}$ Research Scholar, Department of civil engineering, Coimbatore Institute of Technology, Coimbatore- 641 014, Tamil \\ Nadu, India \\ ${ }^{2}$ Associate Professor, Department of civil engineering, Coimbatore Institute of Technology, Coimbatore - 641014 , \\ Tamil Nadu, India
}

\begin{abstract}
The behavior of reinforced concrete moment resisting frame structures in recent earthquakes all over the world has highlighted the consequences of poor performance of beam column joints. Beam column joints in a reinforced concrete moment resisting frame are crucial zones for the transfer of loads effectively between the connecting elements (i.e. beams and columns) in the structure. In 1976, the design of beam column joint is first recommended and subsequently revision is carried out in the year 1985. Design specifications only for the beam column joints are given in IS 13920:1993. There is no provision for the type of column joint whether it be Edge column, Corner column or Interior column. Effect of slab is also not considered in this code. Hence a study and investigation is required on the beam-column joint with slab to suggest improvement in reinforcement detailing based on influence of slab. Two scaled specimens, one Interior Beam-Column joint with slab (BCJS) and another Interior BeamColumn joint without slab (BCJ) were made. Tests were carried out in structural laboratory and the results are discussed here.
\end{abstract}

Keywords: Column joint with slab( BCJS), Beam - Column joint without slab (BCJ), Moment resisting frame, Interior joint, Energy dissipation, Ductility factor.

\section{INTRODUCTION}

In the analysis of reinforced concrete moment resisting frames, the joints are generally assumed as rigid. In Indian practice, the joint is usually neglected for specific design with attention being restricted to provision of sufficient anchorage for beam longitudinal reinforcement. This may be acceptable when the frame is not subjected to earthquake loads. There have been many catastrophic failures reported in the past 50 earthquakes, in particular with Turkey and Taiwan earthquakes occurred in 1999, which have been attributed to beam column joints. The poor design practice of beam column joints is compounded by the high demand imposed by the adjoining flexural members (beams and columns) in the event of mobilizing their inelastic capacities to dissipate seismic energy. Unsafe design and detailing within the joint region jeopardize the entire structure, even if other structural members conform to the design requirements. Since past three decades, extensive research has been carried out on studying the behavior of joints under seismic conditions through experimental and analytical studies. Various international codes of practices have been undergoing periodic revisions to incorporate the research findings into practice.

\section{LITERATURE REVIEW}

Hikmat E.Zerbe et al (1990) studied the seismic response of connections in two bay RC frame subassemblies with a floor. It was found that the presence of slab increases the shear strength in the joints and was not affected by the energy dissipation capacity in continues subassembly. Lateral load resistance increased by as much as 30 percent at 3 percent lateral drift and degradation of stiffness. Based on the results, the suggestion is made to include the effect of a floor slab in the procedure for designing beam-column connections. Gilson N.Guimaraes et al (1992) studied the evaluation of joint-shear provisions for interior beamcolumn slab connections using high-strength materials of four interior beam column slab connections constructed with combinations of normal and high strength and reinforcement are presented and existing joint shear provisions are evaluated for use in designs of connections constructed with high strength materials. Devados Menon et al (2007) conducted a detailed investigation of the design of RC beamcolumn joints. In this study three international code of practice like ACI 318M-02, NZ 3101:1995, pr EN1998-1 were followed for designing the RC beam-column joints under seismic load. The performance specimens which had details as per various codes were compared. They concluded that there is need to revise the code IS13920:1993. This had become inadequate in minimum column width, column/beam flexural strength ratio, and nominal shear strength of beam column joints and effective shear area of joint. Burcu B.Canbolat et al (2008) conducted an experimental investigation on seismic behaviour of eccentric reinforced concrete beam-column-slab connections. The study focused on the effect of eccentricity of spandrel beams with respect to the column. Specimens included a floor slab and transverse beam to evaluate the effect of slab participation. Test results indicated that the floor system significantly reduced the negative influence of eccentricity and observed that damage was reduced. The 
joint shear stresses resisted by the connections, without major damage was higher than the current design values. This was due to the participation of a larger area of the joint region in the resisting shear, which indicates that "recommendations for design of beam column connections in monolithic reinforced concrete structures ( ACI 352R-02) for effective joint width are conservative". Bindu.K.R et al (2008) conducted a detailed investigation on the performance of exterior beam column joints with crossinclined bars under Seismic loading. They investigated the effect of inclined bars at the joint region. Four exterior beam column joint were cast and tested under cyclic load. The specimens which had joint reinforcement as per code IS 13920:1993 with inclined bars and the specimens without inclined bars were tested. They concluded that the specimen with inclined bars showed more ductility and energy absorption capacity than specimen without inclined bars.

\section{EXPERIMENTAL WORK}

\subsection{Material Properties}

The Portland Pozzolana Cement conforming to IS: 1489 1991 is used. Cement was stored in a dry cool place during the course of experimental study. Preliminary tests on cement are conducted as per IS: 4031 - 1988. The results of preliminary tests are given in Table 1.

Table 1 Properties of Cement

\begin{tabular}{|l|l|l|}
\hline S.No & Properties & Test Results \\
\hline 1 & Specific Gravity & 3.15 \\
\hline 2 & Standard Consistency & $33 \%$ \\
\hline 3 & Initial Setting Time & $120 \mathrm{Min}$. \\
\hline 4 & Compressive Strength at 7 days & $32.56 \mathrm{MPa}$ \\
\hline 5 & Compressive Strength at 28 days & $37.85 \mathrm{MPa}$ \\
\hline
\end{tabular}

\subsection{FINE AGGREGATE}

The fine aggregate used in this experimental investigation was natural river sand confirming to zone III of IS: 383 1970. The details of sieve analysis of the fine aggregate are given below in the Table 2 and properties of fine aggregate are given in Table 3 .

Table 2 Sieve Analysis of Fine Aggregate

\begin{tabular}{|c|c|c|c|c|c|c|}
\hline \multirow[t]{2}{*}{ IS Sieve Size } & \multicolumn{3}{|l|}{ Trai-1 } & \multicolumn{3}{|l|}{ Trai-2 } \\
\hline & $\begin{array}{l}\text { Weight } \\
\text { Retained } \\
(\mathrm{gms})\end{array}$ & $\begin{array}{l}\text { Cumulative } \\
\% \text { Retained }\end{array}$ & $\begin{array}{l}\% \text { Weight } \\
\text { Passing }\end{array}$ & $\begin{array}{l}\text { Weight } \\
\text { Retained } \\
\text { (gms) }\end{array}$ & $\begin{array}{l}\text { Cumulative } \\
\% \text { Retained }\end{array}$ & $\begin{array}{l}\text { Weight } \\
\text { Retained } \\
\text { (gms) }\end{array}$ \\
\hline $4.75 \mathrm{~mm}$ & 5.50 & 1.10 & 98.90 & 9.30 & 1.86 & 98.14 \\
\hline $2.36 \mathrm{~mm}$ & 9.1 & 2.92 & 97.08 & 8.1 & 3.48 & 96.52 \\
\hline $1.18 \mathrm{~mm}$ & 29 & 8.72 & 91.28 & 25.7 & 8.62 & 91.38 \\
\hline $600 \mathrm{~m}$ & 84.5 & 25.62 & 74.38 & 77.5 & 24.12 & 75.88 \\
\hline $300 \mathrm{~m}$ & 289 & 83.42 & 16.58 & 298.5 & 83.82 & 16.18 \\
\hline $150 \mathrm{~m}$ & 75.5 & 98.52 & 1.48 & 71.6 & 98.14 & 1.86 \\
\hline $75 \mathrm{~m}$ & 6 & 99.72 & 0.28 & 7.1 & 99.56 & 0.44 \\
\hline Pan & 1.4 & 100 & 0 & 2.2 & 100 & 0 \\
\hline
\end{tabular}

Table 3 Properties of Fine Aggregate

\begin{tabular}{|l|l|l|}
\hline S.No & Properties & Test Results \\
\hline 1 & Fineness Modulus & 2.2 \\
\hline 2 & Specific Gravity & 2.6 \\
\hline 3 & Zone & III \\
\hline
\end{tabular}

\subsection{Coarse Aggregate}

Crushed granite aggregates particles passing through $20 \mathrm{~mm}$ and retained on $4.75 \mathrm{~mm}$ I.S sieve was used as natural aggregates which met the grading requirement of IS: $383-$ 1970. The properties of coarse aggregate are given below in the table 4.

Table 4 Properties of Coarse Aggregate

\begin{tabular}{|l|l|l|}
\hline S.No & Properties & Test Results \\
\hline 1 & Specific Gravity & 2.6 \\
\hline 2 & Water Absorption & $0.15 \%$ \\
\hline
\end{tabular}

\subsection{Water}

Potable water available in the laboratory which satisfies drinking standards was used for the concrete mixing and its subsequent curing.

\subsection{Mix Proportion}

Indian standard Institution has brought out mix design procedure mainly based on the work done in national laboratories. Mix was designed for M20 grade of concrete. These are confirmed in IS: $10262-1982$.

The mix proportion for M20 grade of concrete was 1: 1.65: 2.65 with $\mathrm{W} / \mathrm{C}$ ratio of 0.5 .

\subsection{Strength - Related Test for Concrete}

The specimens were tested for the following test.

1. Cube compressive test

2. Cylinder splitting tensile strength test 


\subsection{Cube Compressive Strength}

For cube, compression testing of concrete, $150 \mathrm{~mm}$ cubes were used .All the cubes were tested in saturated condition, after wiping out the surface moisture as shown Fig. 1. Three cubes were tested at the age of 7 days and 28 days of curing for concrete using compression testing machine of $2000 \mathrm{kN}$ capacity. Test result for compressive strength of cube is given in table 5 and table 6.

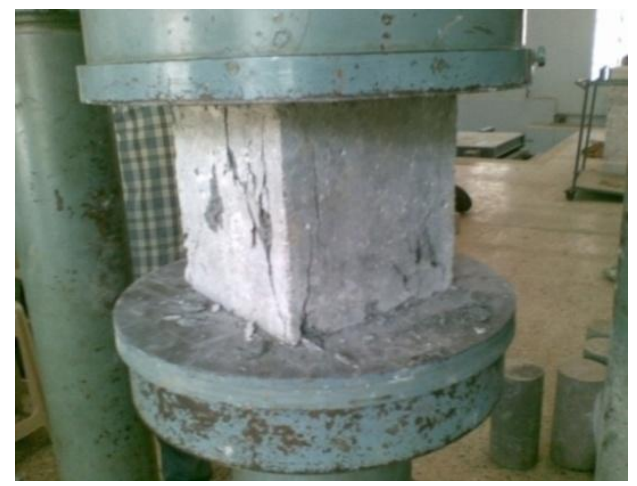

Fig. 1 Compressive strength of cube

Table 5 Compressive Strength OF Cube at 7 Days

\begin{tabular}{|l|l|l|}
\hline S.No & Name of the Specimen & $\begin{array}{l}\text { Compressive } \\
\text { Strength } \\
\mathbf{N} / \mathbf{m m}^{\mathbf{2}}\end{array}$ \\
\hline 1 & $\begin{array}{l}\text { Beam column joint without } \\
\text { slab }\end{array}$ & 18.12 \\
\hline 2 & Beam column joint with slab & 17.36 \\
\hline
\end{tabular}

Table 6 Compressive Strength of Cube at 28 Days

\begin{tabular}{|l|l|l|}
\hline S.No & Name of the Specimen & $\begin{array}{l}\text { Compressive } \\
\text { Strength in } \mathbf{N} / \mathbf{m m}^{\mathbf{2}}\end{array}$ \\
\hline 1 & $\begin{array}{l}\text { Beam column joint } \\
\text { without slab }\end{array}$ & 26.34 \\
\hline 2 & $\begin{array}{l}\text { Beam column joint with } \\
\text { slab }\end{array}$ & 27.36 \\
\hline
\end{tabular}

\subsection{Splitting Tensile Strength}

This is an indirect test to determine the tensile strength of cylindrical specimens. Splitting tensile strength tests were carried out on cylinder specimens of size $150 \mathrm{~mm}$ diameter and $300 \mathrm{~mm}$ length at the age of 28 days curing, using compression testing machine of $2000 \mathrm{kN}$ capacity. The load was applied gradually till the specimens split and readings were noted. The test set up for the splitting tensile strength on the cylinder specimen is shown in Fig. 2.Test result was given in the table 7 . The splitting tensile strength has been calculated using the following formula.

$$
\mathrm{f}_{\mathrm{t}}=2 \mathrm{P} / \pi \mathrm{DL}
$$

Where

$\mathrm{f}_{\mathrm{t}}$ - Splitting tensile strength of the specimen in Mpa

$\mathrm{P}$ - Maximum load in $\mathrm{N}$ applied to the specimen

$\mathrm{D}$ - Measured diameter of the specimen in $\mathrm{mm}$, and

$\mathrm{L}$ - Measured length of the specimen in $\mathrm{mm}$

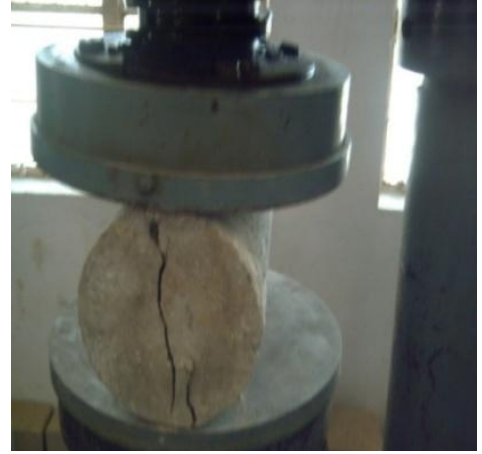

Fig. 2 Split Tensile Test

Table 7 Split Tensile Strength of Cylinder at 28 Days

\begin{tabular}{|l|l|l|}
\hline S.No & Name of the Specimen & $\begin{array}{l}\text { Split tensile } \\
\text { Strength in } \mathbf{N} / \mathbf{m m}^{\mathbf{2}}\end{array}$ \\
\hline 1 & $\begin{array}{l}\text { Beam column joint } \\
\text { without slab }\end{array}$ & 2.829 \\
\hline 2 & $\begin{array}{l}\text { Beam column joint with } \\
\text { slab }\end{array}$ & 3.112 \\
\hline
\end{tabular}

\subsection{Flexural Strength Test}

Beam specimens of size $10 \times 10 \times 50 \mathrm{~cm}$ were cast and tested as shown in Fig. 3 to determine the flexural strength of concrete at the age of 28th days. The bearing surfaces of the supporting and loading rollers are wiped clean, and any loose sand or other material removed from the surfaces of the specimen where they are to make contact with the rollers. The specimen is then placed in the machine in such a manner that the load is applied to the uppermost surface as cast in the mould, along two lines spaced $13.3 \mathrm{~cm}$ apart. The axis of the specimen is carefully aligned with the axis of the loading device. The load is applied without shock and increasing continuously at a rate such that the extreme fibre stress increases at approximately $0.7 \mathrm{~kg} / \mathrm{sq} . \mathrm{cm} / \mathrm{min}$ that is at a rate of $180 \mathrm{~kg} / \mathrm{min}$. The load is increased until the specimen fails, and the maximum load applied to the specimen during the test is recorded.

The flexural strength of the specimen is expressed as the modulus of rupture $\mathrm{fb}$ and the results are given in table 8 .

Where

$$
\mathrm{F}_{\mathrm{b}}=\mathrm{PL} / \mathrm{bd}^{2}
$$

$\mathrm{b}$ - measured width in $\mathrm{cm}$ of the specimen

$\mathrm{d}$ - measured width in $\mathrm{cm}$ of the specimen

$\mathrm{P}$ - maximum load in $\mathrm{kg}$ applied to the specimen, and

$\mathrm{L}$ - Measured length of the specimen in $\mathrm{mm}$

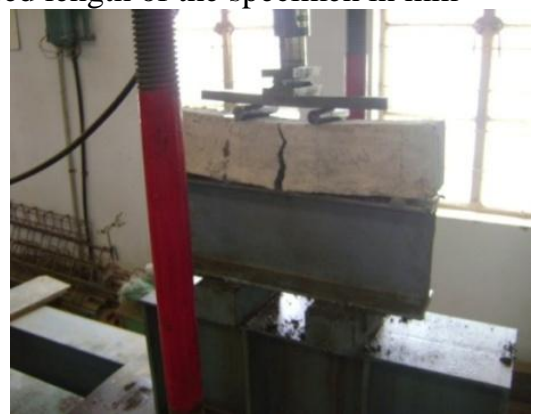

Fig. 3 Tensile Strength of Concrete 
Table 8 Tensile Strength of Concrete at 28 Days

\begin{tabular}{|l|l|l|}
\hline S.No & Name of the Specimen & $\begin{array}{l}\text { Tensile } \\
\text { Strength in } \mathbf{N} / \mathbf{m m}^{2}\end{array}$ \\
\hline 1 & $\begin{array}{l}\text { Beam column joint } \\
\text { without slab }\end{array}$ & 6.534 \\
\hline 2 & $\begin{array}{l}\text { Beam column joint with } \\
\text { slab }\end{array}$ & 5.348 \\
\hline
\end{tabular}

\section{ANALYSIS OF FRAME}

A four storey two bay frames including $1.5 \mathrm{~m}$ foundation depth multistorey reinforced concrete building falling under the seismic Zone - III has been analyzed using STADD.pro. The specimens were designed for seismic load according to IS 1893(Part I): 2002 \& IS 13920: 1993. Based on the critical combination of load, the value for bending moment, shear force and axial forces were taken for the design of Beam - Column joint with slab (BCJS) and Beam - Column joint without slab (BCJ). The maximum moment occurred at the ground floor level. Ground floor interior joint is considered for the experimental work.

The three dimensional view of the building taken for analysis is shown in Fig.4 and elevation is shown in Fig. 5.

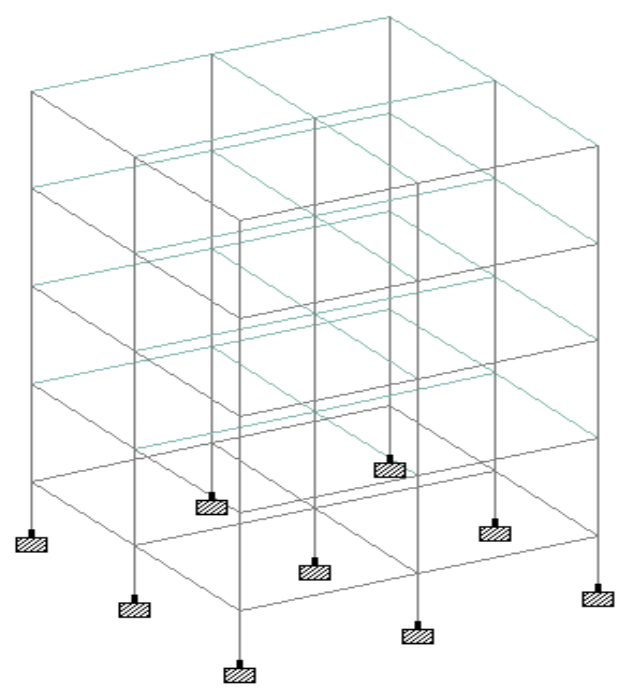

Fig. 4 Three Dimensional View of the Building

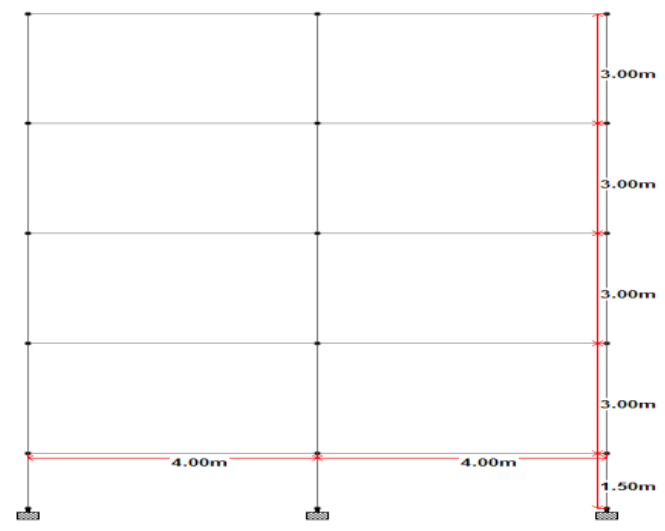

Fig. 5 Elevation of Frame

\section{SPECIMEN}

Beam - Column joint specimen consisted of four numbers of beam (North, South, East and West) and two numbers of column (Top and Bottom).These are monolithically connected at the joint. Another specimen was made as said above with $40 \mathrm{~mm}$ thick slab. Based on the end condition of building the moment coefficient was calculated. Detailing of reinforcements are based on the code Sp 34. Following Fig. 6 shows the detail of reinforcements.

It was difficult to make the test specimens to the original scale to suit the loading arrangement facilities. Hence the test specimens were reduced to one fourth scale. The cross section of the reduced beam was $100 \mathrm{~mm} \times 100 \mathrm{~mm}$ and the cross section of the reduced column was $100 \mathrm{~mm} \times 100 \mathrm{~mm}$. 4 numbers of $10 \mathrm{~mm} \varnothing$ bars were used as main bars in the column. Transverse reinforcement in the column with $6 \mathrm{~mm}$ $\varnothing$ bars at a spacing of $40 \mathrm{~mm} \mathrm{c} / \mathrm{c}$ up to $120 \mathrm{~mm}$ from face of joint and $60 \mathrm{~mm} \mathrm{c} / \mathrm{c}$ for middle portion of $180 \mathrm{~mm}$ and then spacing of $40 \mathrm{~mm} \mathrm{c} / \mathrm{c}$ for the remaining length. 2 numbers of $8 \mathrm{~mm}$ diameter bars as tension reinforcement and 2 numbers of $8 \mathrm{~mm}$ diameter bars as compression reinforcement were used for all beams and stirrups of $6 \mathrm{~mm} \varnothing$ bars at a spacing of $50 \mathrm{~mm} \mathrm{c} / \mathrm{c}$ up to $150 \mathrm{~mm}$ from face of joint and $150 \mathrm{~mm} \mathrm{c/c}$ for middle portion of $300 \mathrm{~mm}$ and then spacing of $50 \mathrm{~mm} \mathrm{c} / \mathrm{c}$ for the remaining length were used .The thickness of the slab was $40 \mathrm{~mm}$.

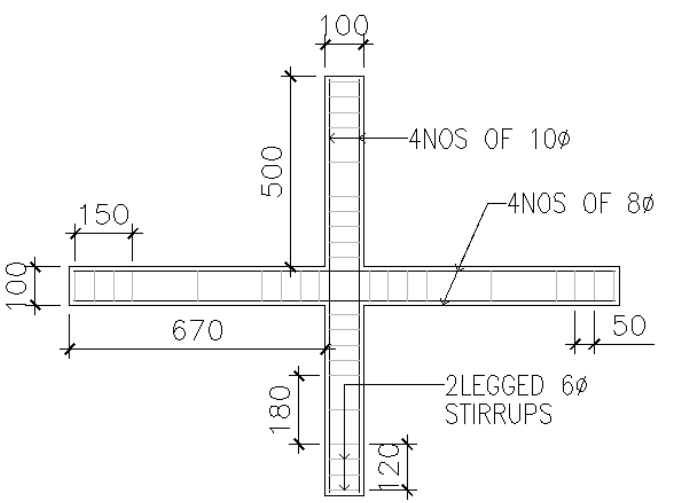

ALL DIMENSIONS ARE IN mm

Fig. 6 Reinforcement Details of Beam-Column Joint Specimen as per the code IS 13920:1993.

The reinforced concrete Beam-Column joint with slab and Beam-Column joint without slab specimens were cast and cured for 28 days. The specimens were placed in the reaction frame and tested under cyclic loading in the structural laboratory. The column ends were provided by pinned connections. On one end of the column, an axial load of $50 \mathrm{kN}$ was applied by using a hydraulic jack of $500 \mathrm{kN}$ capacity. Cyclic load was applied at the free end of all the beams by using a hydraulic jack through load cell. Linear Variable Differential Transducers (LVDTs) were placed on the extreme edge of the all beams to show the deflection that occurred at the point of application of load on the beam. The following Fig. 7 and Fig. 8 show the details of the BCJ and BCJS specimens respectively. 


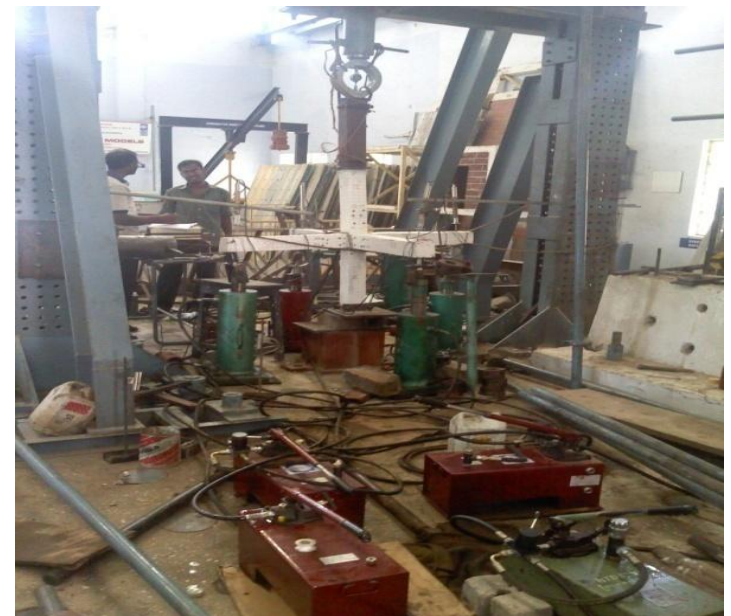

Fig. 7 Beam-Column joint with slab (BCJS) specimen

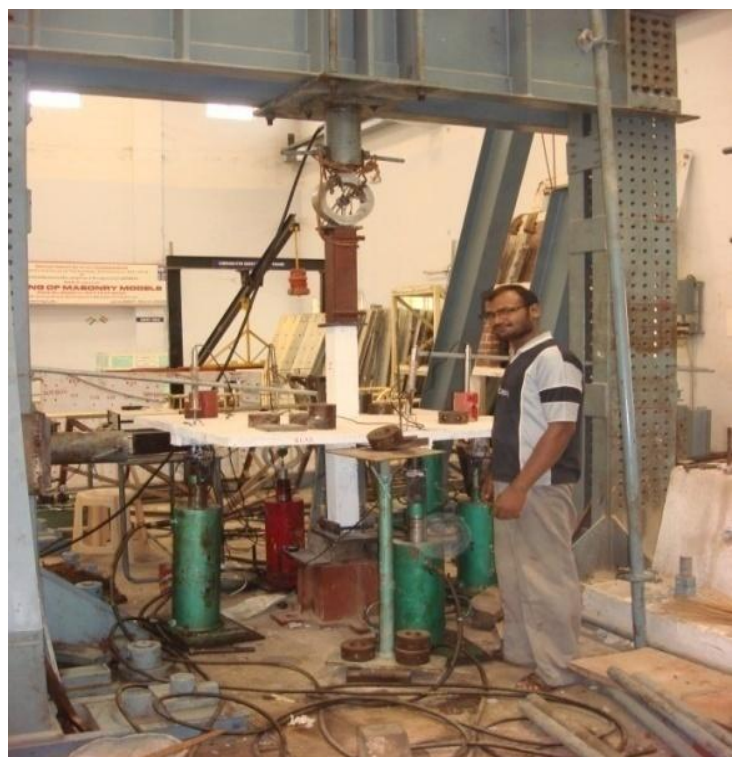

Fig. 8 Beam-Column joint with slab (BCJS) specimen
Tests were carried out for the Beam - Column Joint without slab specimen and Beam - Column Joint with slab specimen and the results were observed at each end of the beam using LVDTs placed at the top of the beam.

\section{RESULTS AND DISCUSSIONS}

\subsection{Load Vs Deflection}

Maximum load and corresponding deflection for each cycle in all the four beams of beam - column joint without slab (BCJ) and beam - column joint with slab (BCJS) specimens are given in Table 9 and Table 10. The maximum Load carrying capacity of BCJ was $20 \mathrm{kN}$ but in BCJS it was 55 $\mathrm{kN}$. Load Vs No.of cycle is also shown in Fig.9 for BCJ and Fig. 14 for BCJS specimen. The deflection of BCJ was maximum in $4^{\text {th }}$ cycle at but it was maximum only at $11^{\text {th }}$ cycle in BCJS. It indicated that the Beam Column Joint with Slab (BCJS) showed better results in Load carrying capacity and in resisting the defection than the Beam Column without Slab (BCJ). Load Vs Deflection curve of all the Beams of BCJ are shown in Fig. 10 to 13 and Load Vs Deflection curve of all the Beams of BCJS are shown in Fig. 15 to 18.

Table 9 Load Carrying of Beam-column Joint without Slab (BCJ) for each cycle

\begin{tabular}{|l|l|l|l|l|l|}
\hline Cycle & $\begin{array}{l}\text { Max. Load } \\
\text { In each cycle }(\mathbf{k N})\end{array}$ & \multicolumn{2}{l|}{ Deflection $(\mathbf{m m})$} \\
\cline { 3 - 6 } & & North Beam & South Beam & East Beam & West Beam \\
\hline $1^{\text {st }}$ Cycle & 5 & 3.2 & 3.4 & 2.8 & 3.0 \\
\hline $2^{\text {nd }}$ Cycle & 10 & 8.2 & 10.5 & 7.6 & 9.8 \\
\hline $3^{\text {rd }}$ Cycle & 15 & 12.3 & 13.2 & 12.5 & 12.9 \\
\hline $4^{\text {th }}$ Cycle & 20 & 21.2 & 22.8 & 21.0 & 21.5 \\
\hline
\end{tabular}




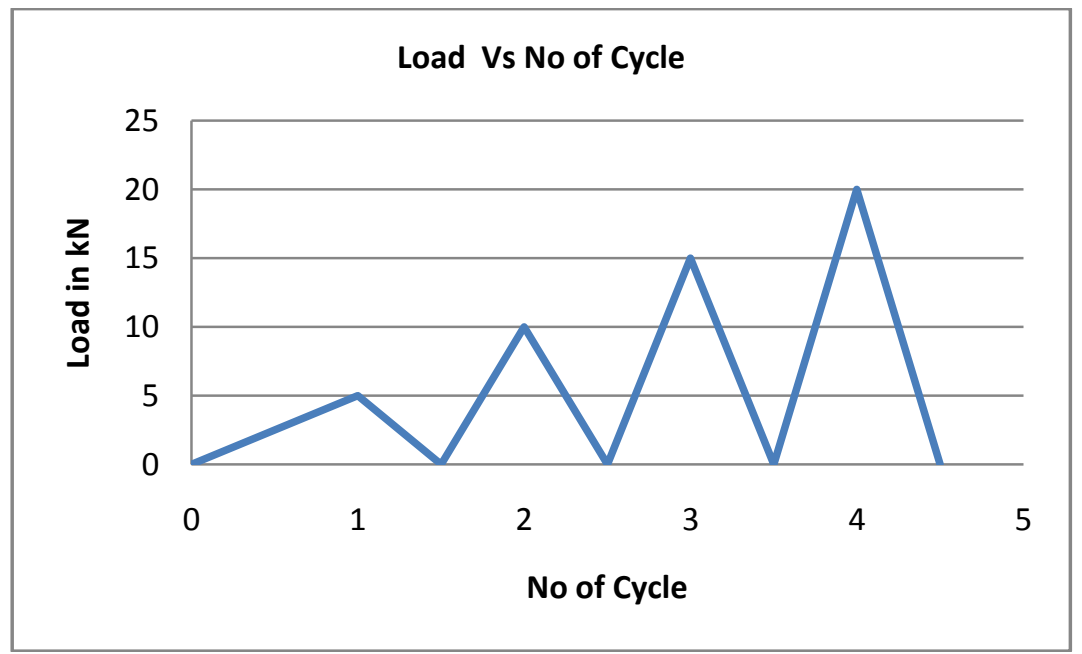

Fig. 9 Load VS No. of Cycle for BCJ

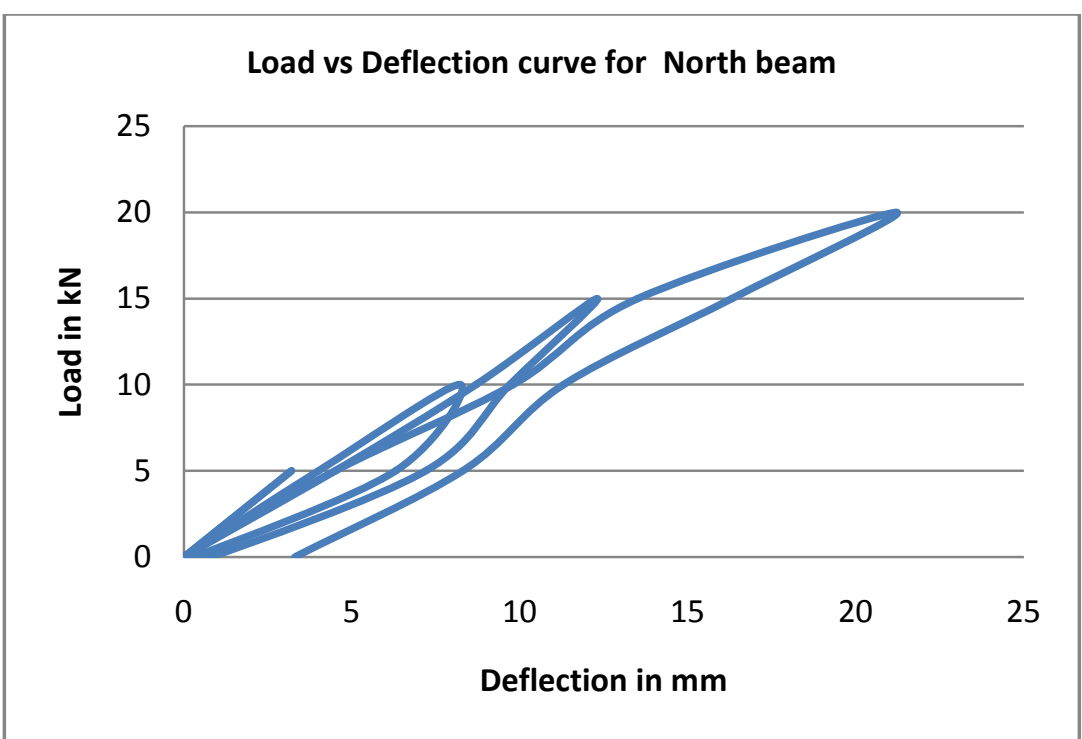

Fig. 10 Load vs. Deflection Curve for North Beam

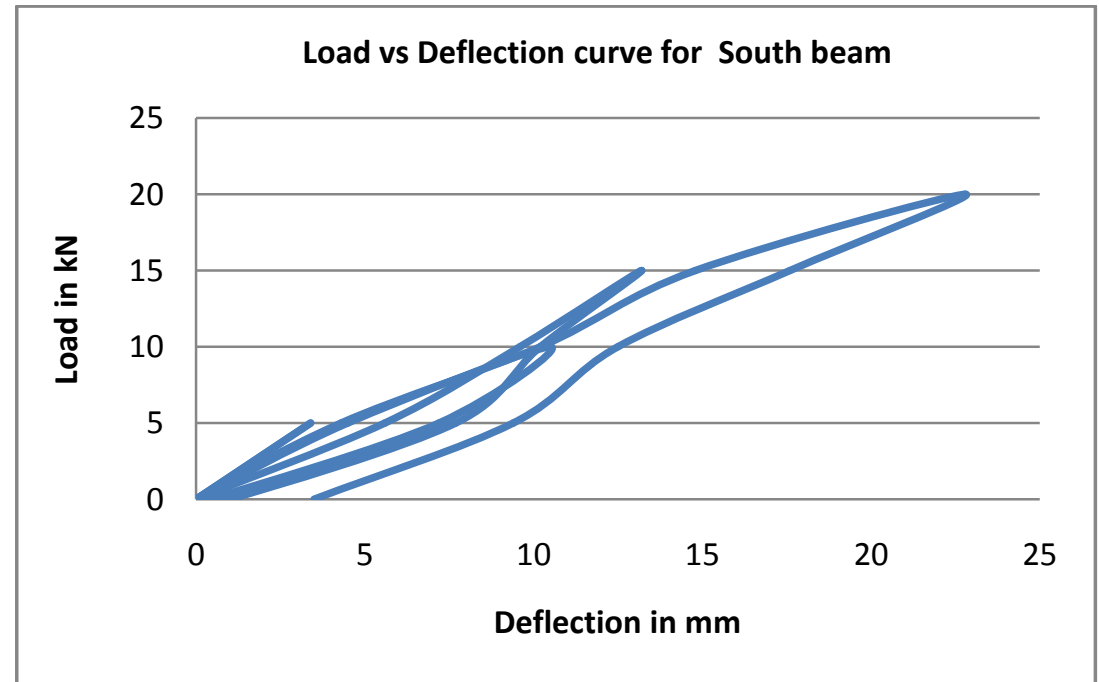

Fig. 11 Load vs. Deflection Curve for South Beam 


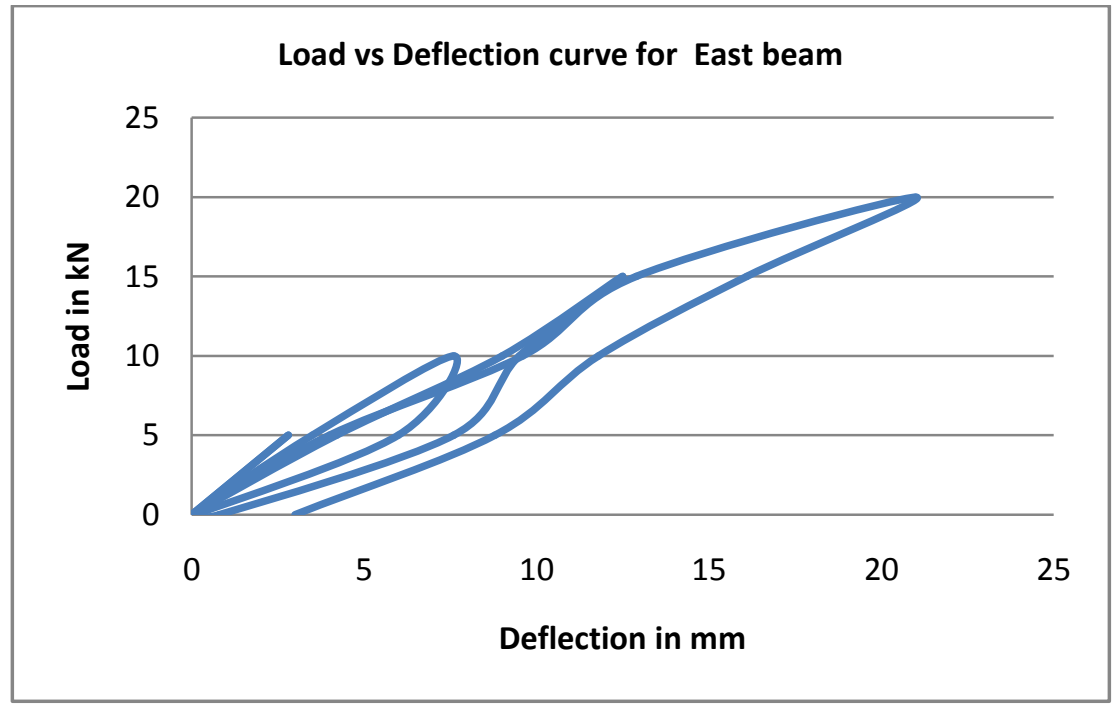

Fig. 12 Load vs. Deflection Curve for East Beam

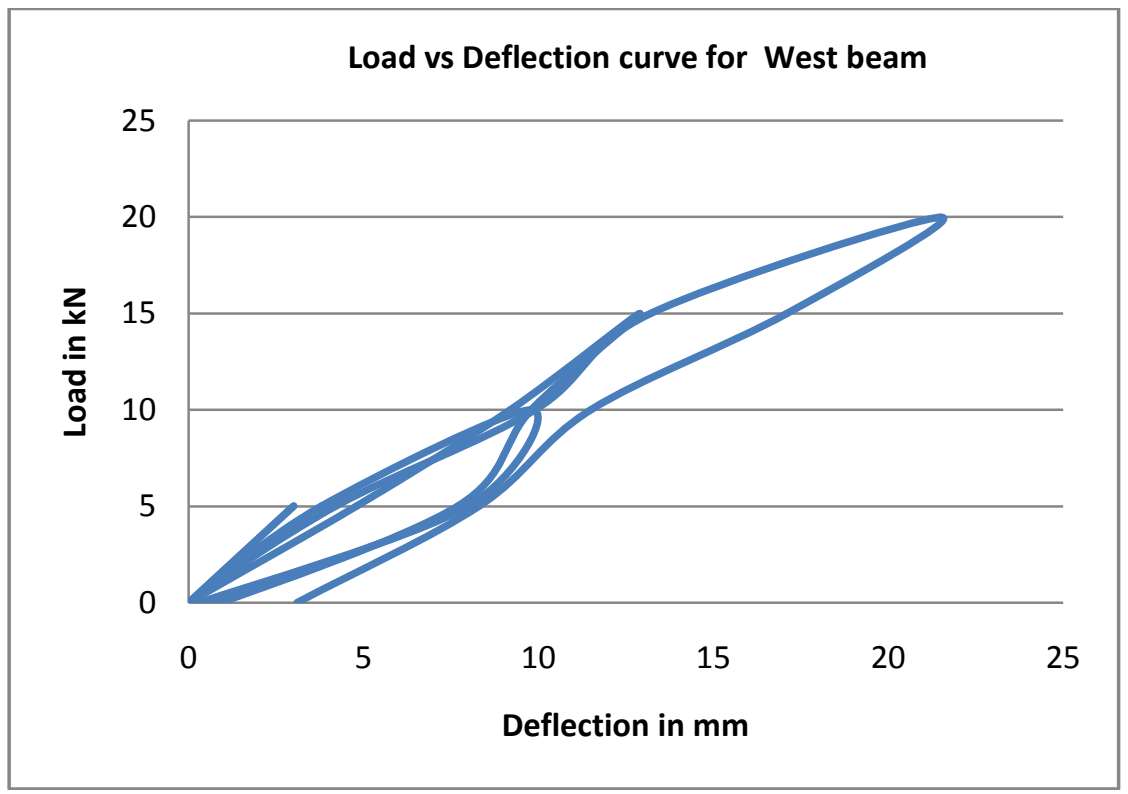

Fig. 13 Load vs. Deflection Curve for West Beam

Table 10 Load Carrying Capacities of Beam- Column Joint With Slab (BCJS) for Each Cycle

\begin{tabular}{|l|l|l|l|l|l|}
\hline \multirow{2}{*}{ Cycle } & $\begin{array}{l}\text { Max. Load } \\
\text { In each cycle }(\mathbf{k N})\end{array}$ & \multicolumn{2}{l|}{ Deflection $(\mathbf{m m})$} & \multicolumn{2}{l|}{} \\
\cline { 3 - 6 } & & North Beam & South Beam & East Beam & West Beam \\
\hline $1^{\text {st }}$ Cycle & 5 & 2.2 & 2.4 & 2.3 & 2.0 \\
\hline $2^{\text {nd }}$ Cycle & 10 & 5.2 & 5.6 & 5.0 & 5.2 \\
\hline $3^{\text {rd }}$ Cycle & 15 & 8.5 & 8.4 & 8.0 & 7.8 \\
\hline $4^{\text {th }}$ Cycle & 20 & 15.6 & 15.3 & 15.4 & 15.0 \\
\hline $5^{\text {th }}$ Cycle & 25 & 18.9 & 18.3 & 18.6 & 18.0 \\
\hline $6^{\text {th }}$ Cycle & 30 & 22.8 & 22.4 & 22.6 & 22.2 \\
\hline $7^{\text {th }}$ Cycle & 35 & 26.5 & 26.3 & 25.8 & 25.8 \\
\hline $8^{\text {th }}$ Cycle & 40 & 29.8 & 29.6 & 29.2 & 29.0 \\
\hline $9^{\text {th }}$ Cycle & 45 & 32.5 & 32.3 & 31.9 & 31.8 \\
\hline $10^{\text {th }}$ Cycle & 50 & 36.8 & 36.4 & 35.8 & 35.6 \\
\hline $11^{\text {th }}$ Cycle & 55 & 40.2 & 39.8 & 38.2 & 38.5 \\
\hline
\end{tabular}




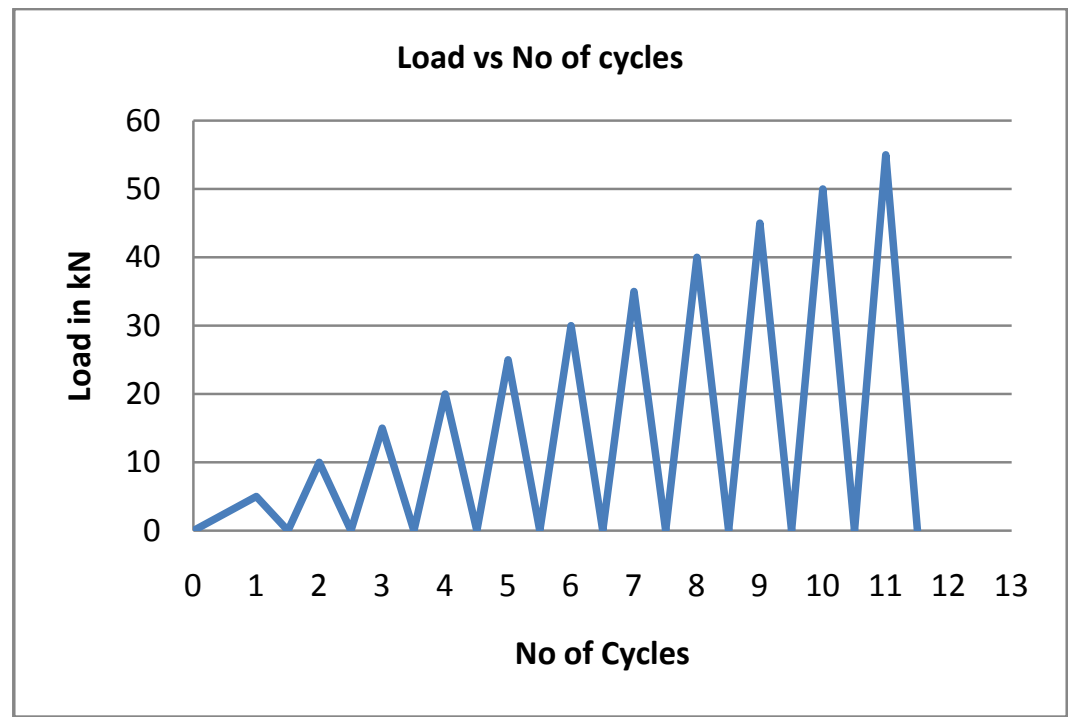

Fig. 14 Load Vs No of Cycle for BCJS

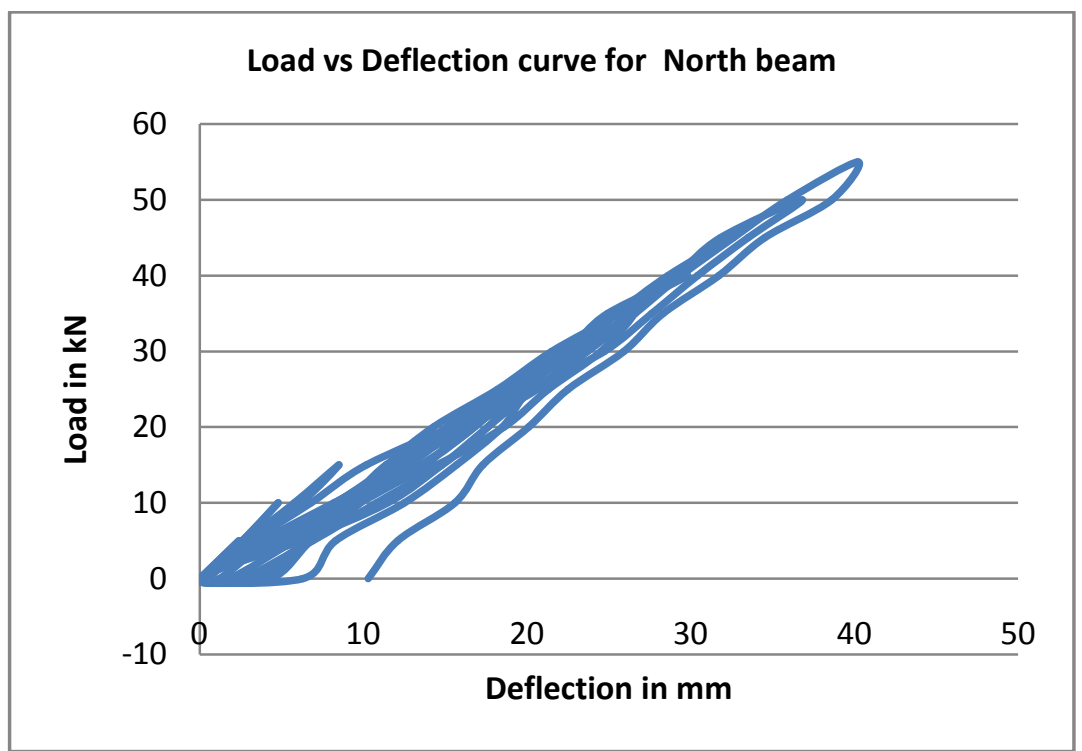

Fig. 15 Load vs. Deflection curve for North Beam

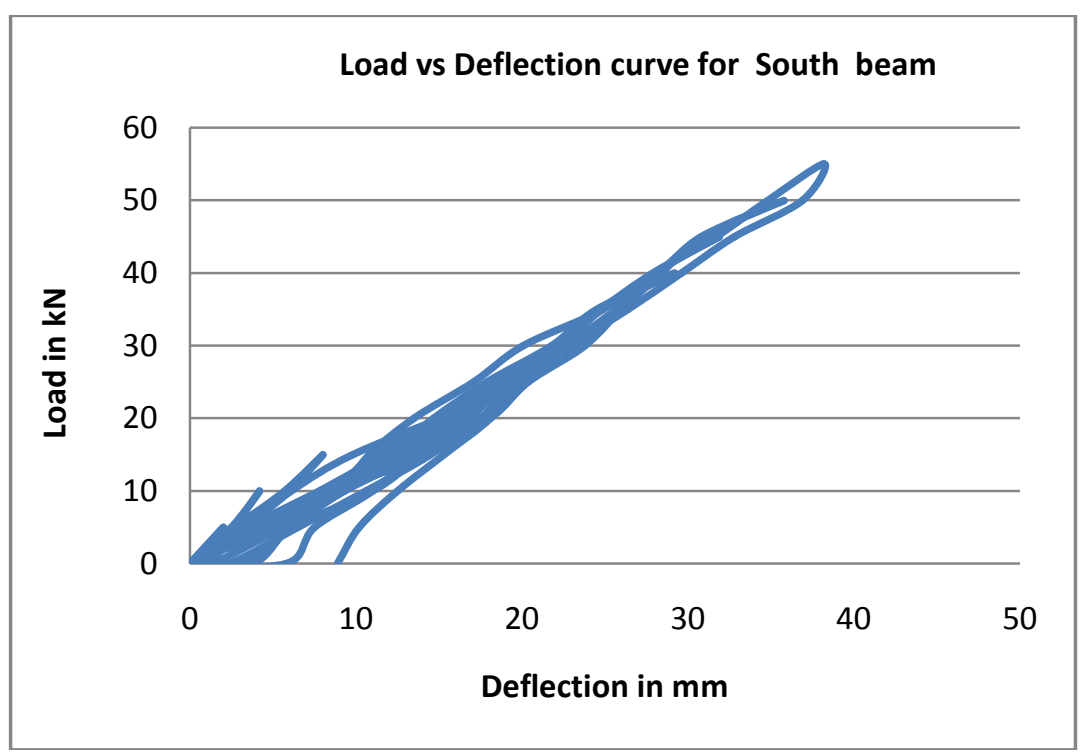

Fig. 16 Load vs. Deflection curve for South Beam 


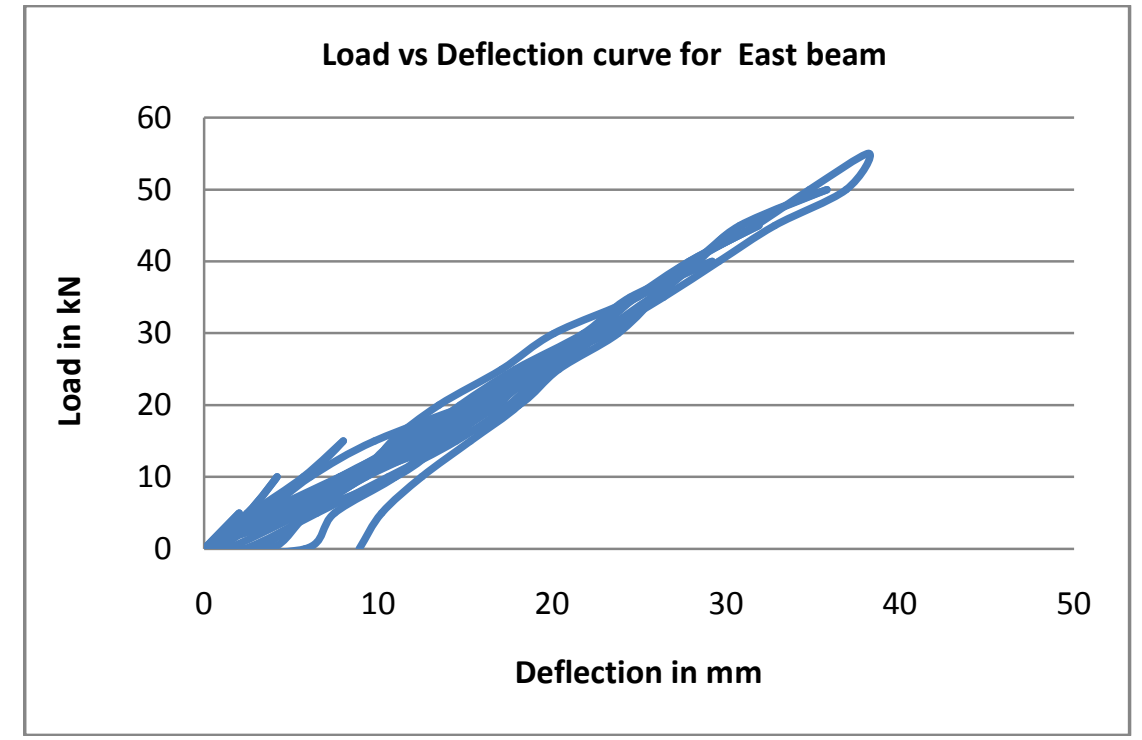

Fig. 17 Load vs. Deflection curve for East Beam

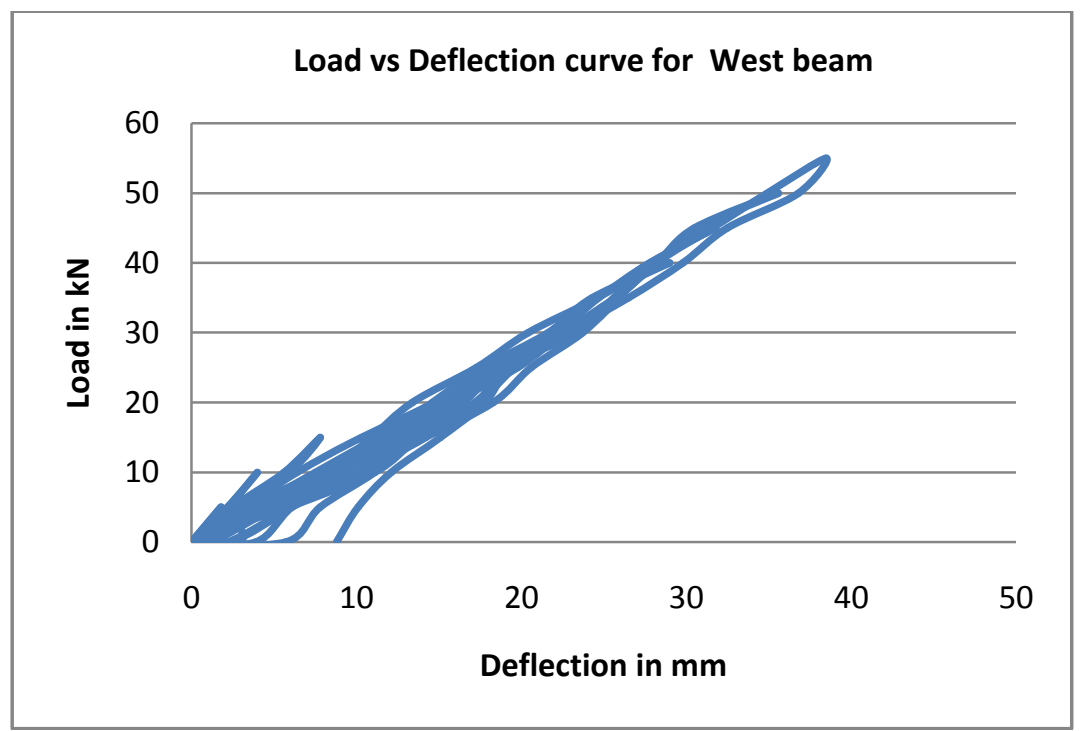

Fig. 18 Load vs. Deflection curve for West Beam

\subsection{Energy Dissipation}

\subsubsection{Energy Dissipation Capacity of BCJ}

The energy dissipation capacity was calculated using the enclosed area of the load deformation curve. Here the test result of beam which was in north direction is chosen for discussion. The energy dissipation of North Beam is shown in Fig. 19.

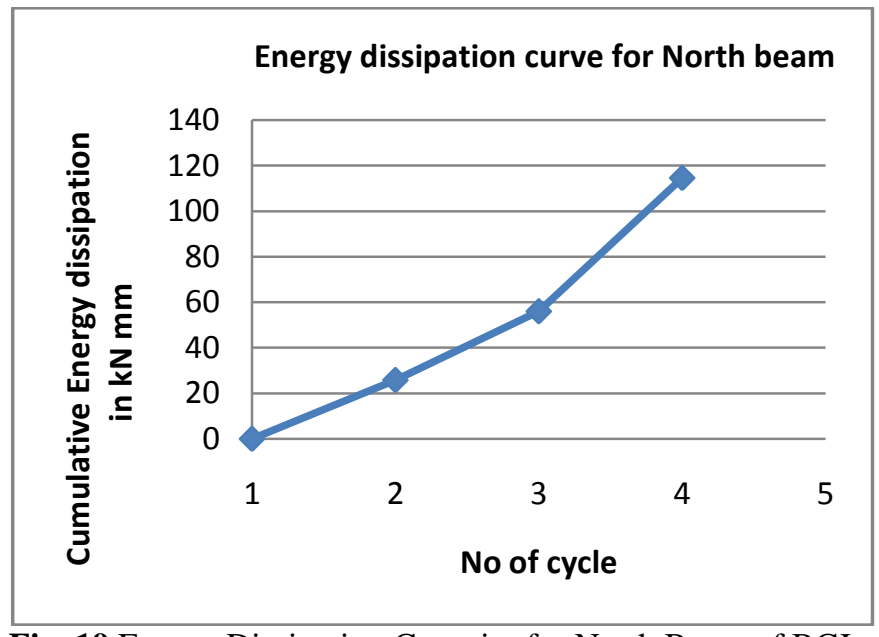

Fig. 19 Energy Dissipation Capacity for North Beam of BCJ 


\subsubsection{Energy Dissipation Capacity of BCJS}

The energy dissipation capacity was calculated using the enclosed area of the load deformation curve. The energy dissipation of North Beam is shown in Fig. 20.

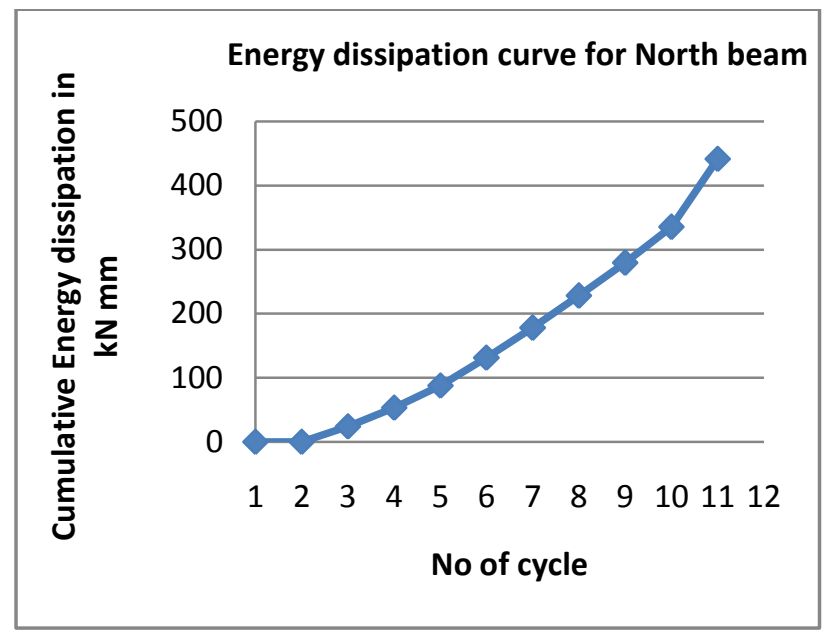

Fig. 20 Energy dissipation capacity for North beam of BCJS

\subsection{Crack Patterns}

In the beam-column joint without slab specimen(BCJ), the cracks developed in the compression and tension side of beam during loading and the bond between concrete and reinforcement were reduced consequently. The first crack occurred near the beam-column junction at $10 \mathrm{kN}$ and further increase in loading, made the cracks propagated and the initial cracks started widening. Ultimate crack developed at beam column joint at $20 \mathrm{kN}$ load. Spalling of concrete is also occurred.Crack pattern is shown in the Fig. 21.

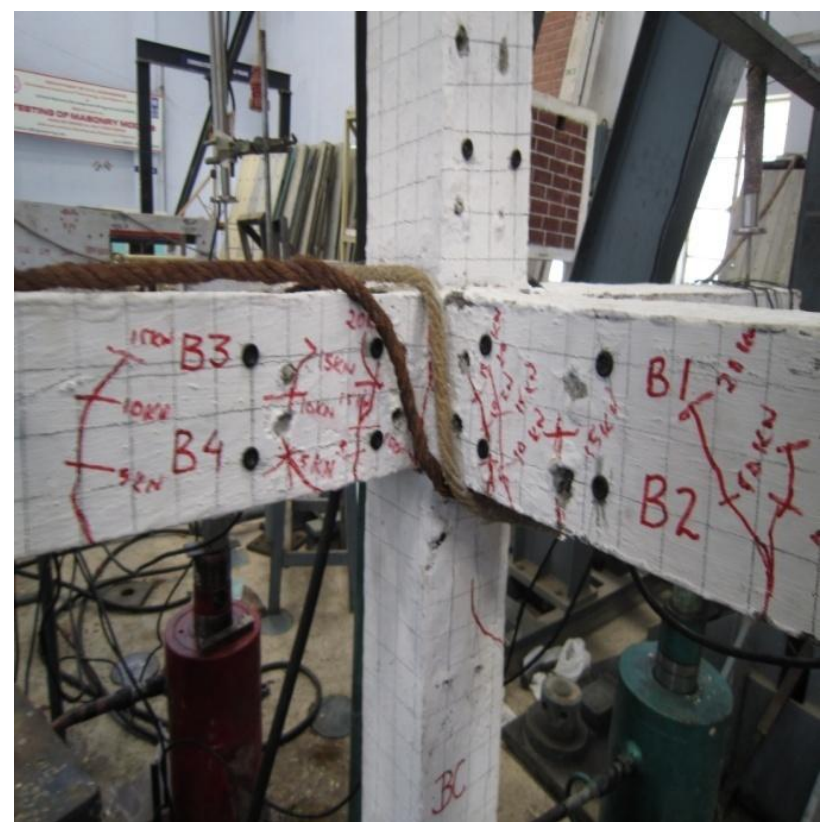

Fig. 21 Crack pattern of Beam-Column joint (BCJ) specimen

In Beam - Column joint with slab specimen(BCJS), the initial cracks were observed at $20 \mathrm{KN}$ on the surface of the slab on further loading this crack was propagated and found running towards beam. Ultimate crack developed at beam column joint at $55 \mathrm{kN}$ load. The deflected shape of the BCJS specimen is given in the Fig. 22.

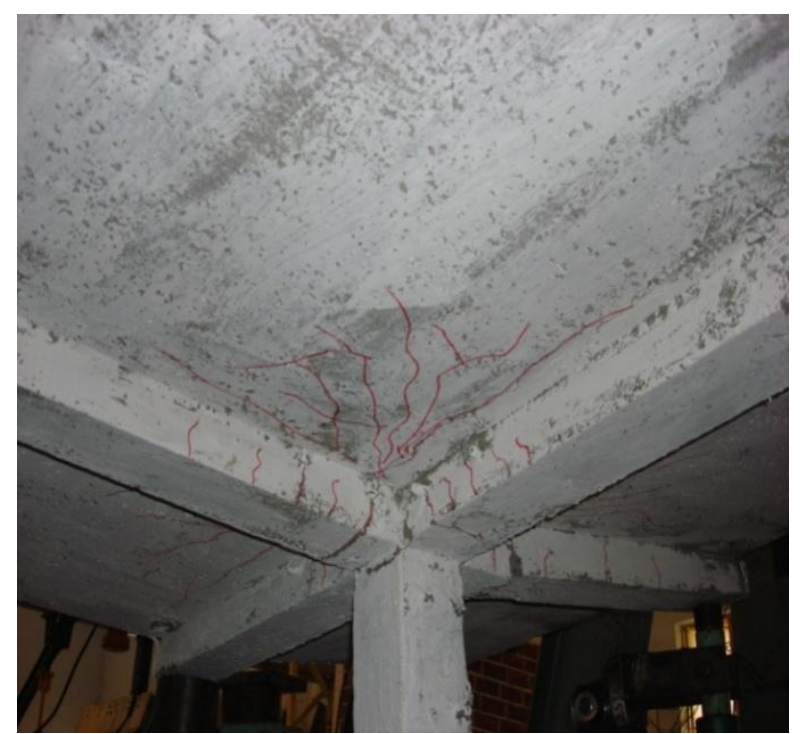

Fig. 22 Crack pattern of Beam-Column joint (BCJ) specimen

\subsection{Ductility Factor}

Ductility is an important characteristic of any structural element. It was described as the capacity of a structural element to undergo deformation beyond yield without losing much of its strength. Ductility has generally been measured by a ratio called ductility factor. It is usually expressed as a ratio of deflection $(\Delta)$ at ultimate stage to the corresponding property at yield as shown below

$$
\text { Displacement ductility factor } \mu_{\Delta}=\Delta_{\mathrm{u}} / \Delta_{\mathrm{y}}
$$

Where $\Delta_{\mathrm{u}}-$ Ultimate displacement and $\Delta_{\mathrm{y}}-$ Yield displacement

From the experiment it was observed that the Ductility factor of BCJS specimen is more when compared to BCJ specimen. The values of displacement ductility factors for BCJ and BCJS are listed in Table 11 and Table 12

Table 11 Ductility Factor of Beam Column Joint Without Slab (BCJ)

\begin{tabular}{|c|c|c|c|c|}
\hline \multirow[t]{2}{*}{ Sl.No } & \multirow{2}{*}{$\begin{array}{l}\text { Beam } \\
\text { Direction }\end{array}$} & \multicolumn{3}{|c|}{ Deflection (mm) } \\
\hline & & $\begin{array}{l}\text { At } \\
\text { Yield } \\
\Delta_{y} \\
\end{array}$ & $\begin{array}{l}\text { At } \\
\text { Ultimate } \\
\Delta_{\mathbf{u}}\end{array}$ & $\begin{array}{l}\text { Ductility } \\
\text { Factor } \\
\boldsymbol{\mu}_{\Delta=(} \Delta_{\mathbf{u} /} \Delta_{\mathbf{v})}\end{array}$ \\
\hline 1 & North & 8.2 & 21.2 & 2.58 \\
\hline 2 & South & 10.5 & 22.8 & 2.17 \\
\hline 3 & East & 7.6 & 21.0 & 2.76 \\
\hline 4 & West & 9.8 & 21.5 & 2.19 \\
\hline
\end{tabular}


Table 12 Ductility Factor of Beam Column Joint With Slab (BCJS)

\begin{tabular}{|l|l|l|l|l|}
\hline Sl.No & \multirow{2}{*}{$\begin{array}{l}\text { Beam } \\
\text { Direction }\end{array}$} & \multicolumn{3}{|c|}{ Deflection $(\mathbf{m m})$} \\
\cline { 3 - 5 } & & $\begin{array}{l}\text { At } \\
\text { Yield } \\
\Delta_{\mathbf{y}}\end{array}$ & $\begin{array}{l}\text { At } \\
\text { Ultimate } \\
\Delta_{\mathbf{u}}\end{array}$ & $\begin{array}{l}\text { Ductility } \\
\text { Factor } \\
\boldsymbol{\mu}_{\Delta=(} \Delta_{\mathbf{u}} / \Delta_{\mathbf{y}}\end{array}$ \\
\hline 1 & North & 8.5 & 40.2 & 4.37 \\
\hline 2 & South & 8.4 & 39.8 & 4.74 \\
\hline 3 & East & 8.0 & 38.2 & 4.78 \\
\hline 4 & West & 7.8 & 38.5 & 4.94 \\
\hline
\end{tabular}

\section{SUMMARY}

An experimental investigation was carried out on BCJ and BCJS specimen under cyclic loading. The Results of the experimental study on BCJ specimen and BCJS specimen were analyzed and compared to reach the concluding points.

In BCJS specimen, it is obviously noticeable that the yield load carrying capacity was 2 times more than that of the BCJ specimen and also the ultimate load carrying capacity was 2.75 times more than that of the BCJ specimen. It is also clear that in the BCJS specimen, the energy dissipation capacity of North beam were observed as 3.85 times more than that of the BCJ specimen.

Noticing the crack pattern in the BCJS and BCJ, a significant difference was observed. In BCJS first crack was observed at the top of slab and it propagated towards the beam, but in BCJ specimen first crack was observed at Beam - Column joint itself and it widened for further loading. On finding the different facts of the ductility factor of North beam in BCJS was increased by 1.83 times than that of BCJ specimen.

\section{CONCLUSIONS}

Referring the existing pattern, Indian standard for earthquake resistant design of structures IS 1893 and Indian standard for ductile detailing of reinforced concrete structures IS 13920 do not have any provisions for Beam Column Joint with Slab. So it is hereby recommended that the strength of slab plays an important role in beam column joint and it should be considered and the corresponding details have to be included in these Indian standards.

\section{REFERENCES}

[1] Hikmat E.Zerbe and Ahmad J.durrani , 1990, "Seismic Response of Connections in two-bay R / C Frame subassemblies " Journal of structural engineering, vol.115, No.11, Pg. 2829-2843.

[2] Gilson N.Guimaraes et al, 1992, "Evaluation of Joint-Shear Provisions for Interior Beam-Column Slab Connections Using High-Strength Materials", ACI structural journal, Vol. 89,No.1.,Pg. 89-98.

[3] Devados Menon et al, 2007, "Design of RC Beam Column Joints Under Seismic Loading - A Review". Journal of structural engineering 2007, Vol. 33, Pg. 449-457.
[4] Burcu B.Canbolat and James K.Wight, 2008, "Experimental Investigation on Seismic Behaviour of Eccentric Reinforced concrete Beam-Column-Slab Connections", ACI structural journal, Vol 105, No.2, Pg. 154-162

[5] K.R.Bindu and K.P.Jaya, 2008, "Performance of Exterior Beam Column Joints With Cross - Inclined Bars Under Seismic Type Loading", Journal of Engineering and Applied Science, 2008 ,Vol 7, Pg. 591-597.

[6] IS:13920-1993, 1993, "Indian Standard code of practice for ductile detailing of concrete structures subjected to seismic forces", Bureau of Indian Standards, New Delhi.

[7] P.C. varghese, 2006, "Advanced reinforced concrete design", Prentice hall of India private limited . 